\title{
PEMANFAATAN KOTORAN TERNAK SEBAGAI ENERGI TERBARUKAN MELALUI PEMBANGUNAN BIODIGESTER KOMUNAL
}



Zhuniart Ayu Perdanasari

Mahasiswa S1

Universitas Brawijaya Jurusan Perencanaan Wilayah dan Kota

zhuniartayu@gmail.com

Dian Dinanti

Tenaga Pengajar (Dosen) Universitas Brawijaya Jurusan Perencanaan Wilayah dan dinanti@ub.ac.id
The potentials of energy from manure waste was calculated in this study aiming to develop biogas utilization in a rural area. The calculation was conducted based on the result from clustering the non-biogas farmer households which cannot afford individual anaerobic digester (AD). Spatial cluster analysis (SCA) and superimposed technique were used to determine the size of the groups and the location of ADs respectively. Value from SCA showed that the village's settlement pattern is clustered feasible to apply communal $A D$ for rural biogas development. Meanwhile, a superimposed technique using 3 parameters which are land availability, cow ownership, and topography, generates 43 clusters of farmer households that can supply biogas for cooking. The energy production is estimated at 8.96-39.68 m3/day/household, while the energy demand is approximately 0.65-3.48 m3/day/household. The calculation shows that there is remaining biogas that can be distributed to non-biogas farmer households. Using SCA, 75 non-biogas farmer households were identified to be potentially supplied by biogas. The total energy demand for both biogas and non-biogas farmers households is 2,147.34 MJ/day, while the total potential energy generation from all $A D s$ is 24,560.64 MJ/day indicating a low biogas utilization rate which is only $8.7 \%$. The percentage shows that biogas utilization for an energy source in Dusun Dresel can be more developed by enhancing the distribution network or by converting it into electricity to support rural energy security.

Keywords: Spatial Cluster Analysis, Biogas, Overlay Technique, Livestock Manure Waste.

\section{PENDAHULUAN}

Pemerintah Indonesia menargetkan untuk meningkatkan bauran energi terbarukan dari $6 \%$ pada tahun 2010 menjadi $25 \%$ pada tahun 2025 dimana $10,81 \%$ berasal dari biomassa dan turunannya termasuk biogas. Beberapa peraturan terkait pengembangan energi terbarukan telah disahkan untuk pencapaian target tersebut. Pemanfaatan biogas cenderung meningkat di Indonesia karena memiliki manfaat sosial, ekonomi dan lingkungan [1]. Pemanfaatan biogas akan meningkatkan kesadaran masyarakat akan energi hijau, mengurangi emisi gas rumah kaca (GRK), mempromosikan pembangunan desa berkelanjutan, mempercepat pembangunan pertanian berkelanjutan, meningkatkan pendapatan rumah tangga serta meningkatkan pemerataan energi dan perbaikan kualitas $[2,3,4]$.

Konsumsi energi final bergeser dari ketergantungan pada energi konvensional ke pendayagunaan energi terbarukan lokal untuk penghematan energi dan konservasi lingkungan $[5,6]$. Kondisi tersebut merupakan peluang bagi pengembangan energi terbarukan, tetapi pengembangan energi terbarukan, khususnya di pedesaan, relatif lambat akibat biaya awal yang tinggi, yaitu biaya produksi, penelitian, pengembangan, dan pelaksanaan $[7,8]$ ). Hambatan lain adalah faktor ketergantungan pada faktor geografis karena dua alasan. Pertama, penyediaan (supply) biomassa sebagai input AD dan kebutuhan (demand) biogas sering kali letaknya tersebar [9]. Kedua, terdapat persyaratan spasial dan teknis untuk menentukan lokasi pengolahan biogas, misalnya ketersediaan dan kesesuaian lahan, kedekatan lahan dengan kandang maupun rumah dengan lahan 
yang membutuhkan data geografis yang lengkap dan detil [10]. Kedua faktor tersebut membutuhkan data spasial yang akurat guna perencanaan biogas pedesaan yang terpadu. Sistem informasi geografis (SIG) dapat digunakan untuk menghasilkan perencanaan spasial terkait pengembangan energi biogas di pedesaan.

Berdasarkan Outlook Energi Indonesia tahun 2015, konsumsi energi final di Indonesia meningkat dari 778 juta SBM pada tahun 2000 menjadi 1,211 juta SBM pada tahun 2013 (rata-rata peningkatan sebesar 3,46\% per tahun). Angka ini akan terus meningkat seiring dengan pertumbuhan penduduk Indonesia setiap tahunnya sehingga berimplikasi pada jumlah permintaan energi yang berbanding terbalik dengan penawaran energi yang terbatas di Indonesia [11]. Peningkatan jumlah permintaan energi terjadi karena Indonesia masih mengandalkan penggunaan energi tak terbarukan seperti penggunaan bahan bakar fosil yang memiliki tingkat produksi jauh lebih lambat dibandingkan dengan tingkat konsumsinya, sehingga, pemanfaatan sumber-sumber energi alternatif yang terbarukan dan ramah lingkungan menjadi pilihan untuk dikembangkan. Hal ini seiring dengan target pemerintah dalam Kebijakan Energi Nasional (KEN) melalui PP 79/2014, yaitu target optimal bauran energi baru dan terbarukan (EBT) yaitu 23\% di 2025 dan 31\% di 2050 [11] dimana salah satu sumber EBT yang digunakan adalah biomassa dan turunannya termasuk biogas. Penelitian terkait penggunaan biomassa sebagai EBT sudah banyak dilakukan di Indonesia, misalnya oleh [12] dan [13]. [12] mengukur nilai kalor briket ampas batang tebu dan serbuk gergaji sedangkan [13] mengukur pengaruh tekanan dan komposisi bahan briket terhadap karakteristik pembakaran. Kedua penenlitian tersebut menjukkan bahwa biomassa layak digunakan sebagai alternative pengganti energi fosil. Biomass yang diolah secara anaerobik (tanpa oksigen) akan menghasilkan biogas.

Biogas merupakan salah satu solusi energi alternatif ramah lingkungan. Biogas mudah digunakan khususnya untuk kalangan masyarakat pedesaan yang memelihara hewan ternak sapi. Berkaitan dengan permasalahan tersebut maka pemanfaatan limbah kotoran ternak dioptimalkan sehingga dapat menekan biaya tanpa mengganggu produktivitas ternak. Keuntungan atau nilai tambah terkait penggunaan biogas adalah memperkecil volume limbah yang dibuang, memperoleh bahan bakar berkualitas tinggi, dan menurunkan emisi gas metana $[14,15]$. Pemanfaatan limbah ternak menjadi biogas dapat memberi nilai tambah dengan peningkatan pendapatan (keuntungan/profit) pada petani dan peternak [16, 17]. Selain itu, pengolahan kotoran ternak biogas dapat meningkatkan kebersihan dan menekan pencemaran lingkungan [18]. Konversi biogas dari limbah ternak dilakukan dengan menggunakan anaerobic digester (AD).

Desa Oro-oro Ombo salah satu desa di Kecamatan Batu, Kota Batu yang memiliki potensi ternak tertinggi dari 8 desa yang ada Kecamatan Batu. Mulai tahun 2007 Kecamatan Batu menjadi target utama program pengembangan biogas yang salah satunya diterapkan di Desa Oro-oro Ombo. Alasan pemerintah memilih program biogas di Desa Oro-oro Ombo adalah mengendalikan pencemaran akibat limbah dari usaha para peternak sapi yang terdapat di wilayah Desa Oro-Oro Ombo. Desa Oro-oro Ombo memiliki potensi ternak yang tinggi dengan jumlah ternak sapi perah sebanyak 2.184 ekor sehingga pemerintah juga menargetkan desa tersebut menjadi desa mandiri energi (DME). Dusun Dresel merupakan dusun di Desa Oro-Oro Ombo dengan populasi ternak tertinggi. Populasi ternak yang tinggi membuat Pemerintah Kota Batu memutuskan untuk memberikan hibah reaktor biogas di Dusun Dresel pada tahun 2015. Pemanfaatan biogas menjadi peluang kemandirian energi bagi peternak. Program pembangunan biogas di Dusun Dresel sudah dimulai sejak tahun 2007 sehingga pemerintah setempat mentargetkan menjadi desa mandiri energi, namun hanya 14 reaktor biogas yang dibangun dan didistribusikan ke beberapa KK hingga tahun 2019. Hal ini disebabkan beberapa kendala antara lain; biaya kontruksi yang tinggi, syarat jumlah minimal ternak, syarat luas minimal sisa lahan dan kurangnya informasi.

Penelitian ini bertujuan untuk menentukan lokasi reaktor biogas khususnya biogas komunal bagi KK peternak yang belum memiliki AD. Berdasarkan [19], salah satu solusi untuk meningkatkan kemampuan membayar peternak dalam membangun reaktor biogas adalah dengan pengelompokan peternak.

\section{METODE DAN BAHAN}

\subsection{Teknik Sampling}

Populasi dalam penelitian ini adalah masyarakat peternak dan non peternak di Desa Oro-oro Ombo, Dusun Dresel. Masyarakat peternak dan non peternak di kelompokkan sesuai dengan kebutuhan energi memasak tiap rumah tangga (RT). Pengelompokan tersebut menggunakan kriteria ketersediaan lahan, kepemilikan ternak, dan kondisi kontur. Berdasarkan hasil survei, jumlah RT peternak sapi perah di Dusun Dresel sebanyak 198 RT dan jumlah non peternak sebanyak 109 RT. Semua RT digunakan sebagai sampel dalam penelitian ini sebagai sampel jenuh sehingga total responden adalah 307 RT. 


\subsection{Penggunaan SIG untuk Penentuan Lokasi AD Format dari Sub-bab.}

Penentuan lokasi AD menggunakan spatial cluster analysis dan teknik superimpose dengan bantuan sistem informasi geografi (SIG) menggunakan software ArcGIS. Teknik SIG telah luas digunakan untuk solusi permasalahan terkait keruangan dan juga penilaian lokasi potensi biomassasa guna produksi biogas. Teknik ini juga sudah sering digunakan untuk menentukan lokasi AD di pedesaan [20,21]. [22] menggunakan pendekatan SIG untuk menentukan lokasi AD melalui identifikasi sumber biomassas yang potensial. Evaluasi lokasi AD yang tepat berdasarkan system pengumpulan limbah ternak telah dilakukan oleh [23] dan [24], sedangkan perangkat berbasis SIG dikembangkan oleh [25] untuk menghitung ketersediaan limbah ternak dan memperkirakan volume biogas yang tersedia. SIG juga telah dipelajari untuk memperkirakan distribusi secara regional potensi biogas berdasarkan volume limbah ternak. Negara-negara berkembang khususnya Indonesia mengalami kendala dalam pembangunan $\mathrm{AD}$ karena sebagian besar rumah tangga tidak mampu untuk membangun AD secara individu karena tingginya biaya pembangunan [26, 27].. Salah satu solusi yang dapat digunakan untuk mengingkatkan keterjangkauan masyarakat pedesaan terhadap pembangunan AD adalah dengan pengelompokan [28]. Salah satu metode yang dapat digunakan untuk pengelompokan adalah melalui teknik tumpang tindih (overlay) dan spatial cluster analysis (SCA).

\subsubsection{Teknik Tumpang Tindih (Overlay)}

Penelitian ini menggunakan teknik overlay yang merupakan proses penyatuan data dari lapisan layer yang berbeda. Menurut [29], Teknik Overlay proses adalah penyatuan data dari lapisan layer yang berbeda berupa peta individu yang memiliki informasi/database yang spesifik sehingga menghasilkan sistem informasi dalam bentuk grafis. Penyusunan peta dilakukan minimal dengan dua jenis peta yang berbeda. Secara teknis, pada teknik ini harus ada polygon yang terbentuk daridua jenis peta yang disusun yang jika dilihat data atributnya, maka peta akhir akan terdiri dari informasi peta pembentukya. Sebagai contoh, overlay peta topografi dengan peta penggunaan lahan akan menghasilkan peta baru yang berisi atribut topografi dan penggunaan lahan. Agregat dari kumpulan peta individu ini, atau yang biasa disebut peta komposit, mampu memberikan informasi yang lebih luas dan bervariasi. Prosedur dalam teknik overlay meliputi [30]:

1. Membuat peta dasar dari wilayah studi

2. Membuat peta - peta lain sesuai kebutuhan dalam studi

3. Menentukan kriteria sesuai dengan kebutuhan studi

4. Melakukan overlay antar peta yang satu dengan yang lain sesuai kebutuhan

Pada penelitian ini terdapat 3 peta tematik yang digunakan pada teknik overlay, yaitu peta ketersediaan lahan, kepemilikan ternak dan kontur tanah. Ketiga peta tersebut saling disusun menggunakan Teknik overlay dimana masing-masing peta memiliki criteria sebagai alat untuk mengidentifikasi apakah variable ketersediaan lahan, kepemilikan ternak dan kontur tanah di lokasi studi memenuhi syarat pembangunan AD. Hasil overlay adalah peta pengelompokan peternah yang digunakan untuk dasar penentuan pengelompokan peternak non-biogas. Sedangkan pengelompokan non-peternak didasarkan kepada jumlah energi yang dapat didistribusikan oleh peternak non-biogas yang membangun digester. Proses penentuan kelompok peternak dapat dilihat pada Gambar 1.



Gambar 1: Proses pada Teknik Overlay

\subsubsection{Spatial Cluster Analysis (SCA)}

SCA biasanya digunakan untuk menganalisis pola distribusi data obyek dengan pertimbangan kedekatan. Kedekatan tersebut menggambarkan kemiripan karakteristik obyek-obyek. Kedekatan dan batas klaster 
dihitung menggunakan K-Nearest Neighbor Method dmana nilai yang dihasilkan mengindikasikan jarak ratarata obyek dan hasilnya bias berupa terklaster, acak atau menyebar. Variabel yang digunakan dalam penelitian ini adalah persil rumah sebagai obyek-obyek yang akan dianalisis dan luas guna lahan permukiman sebagai hamparan sebaran persil rumah. Data yang diinput dan diproses menggunakan SIG menghasilkan beberapa nilai yang akan dibandingkan dengan nilai kritis yang telah ditentukan untuk masing-masing pola permukiman sehingga pola permukiman di Dusun Dresel dapat diidentifikasi berdasarkan nilai kedekatan yang dihasilkan yang merupakan jarak rata-rata antar persil. Pola permukiman ideal untuk pembangunan AD komunal adalah terklaster. Pola permukiman terklaster harus memenuhi kriteria nilai yang kritis sebagai berikut: (i) Rasio tetangga terdekat (nearest neighbor ratio) tidak lebih dari 1, (ii) Z-score tidak lebih dari 2.58, (iii) p-value maksimal 0.01 for, z-score. Proses yang dilakukan pada SCA ditunjukkan pada Gambar 2.

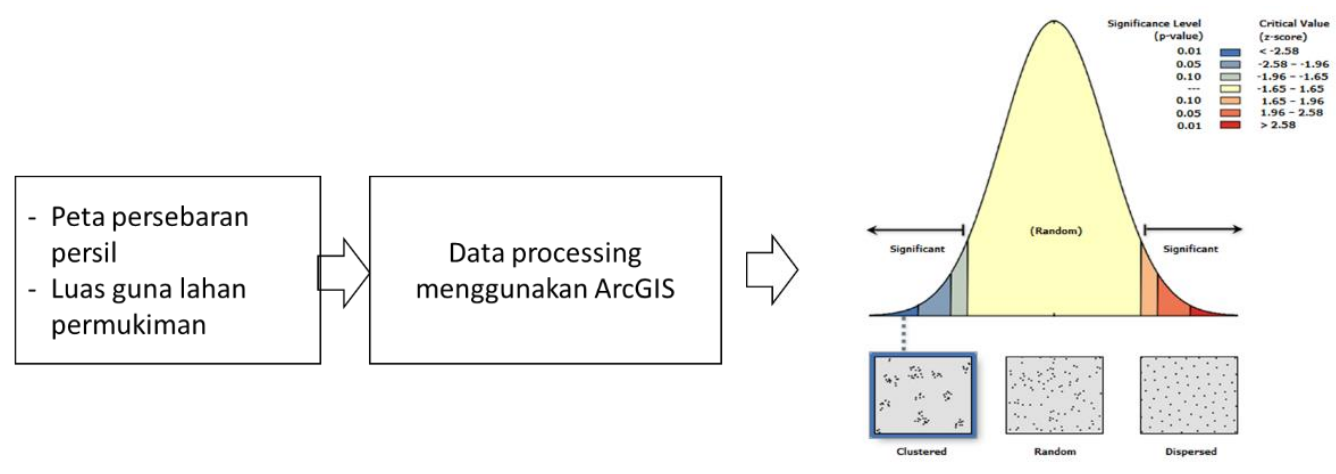

Gambar 2: Proses pada Spatial Cluster Analysis.

\subsubsection{Perhitungan Potensi Produksi dan Kebutuhan Energi Biogas}

Perhitungan potensi energi biogas dari pemanfaatan limbah ternak sapi di Desa Oro-oro Ombo dilakukan karena tidak dilakukan pengukuran langsung terhadap sample kotoran ternak akibat keterbatasan alat. Oleh karena itu, perhitungan potensi energi biogas menggunakan beberapa asumsi berdasar pada hasil survei dan teori dari para ahli. Asumsi-asumsi tersebuat adalah:

\section{Potensi Gas per unit kotoran sapi}

Menurut [31] potensi gas yang dihasilkan per kg berat kotoran sapi atau kerbau sebesar 0,023-0,040 $\mathrm{m}^{3}$. Nilai potensi gas sebesar $0,040 \mathrm{~m}^{3} / \mathrm{kg}$ kotoran sapi digunakan pada penelitian ini berdasar wawancara dengan staf BIRU di Kecamatan Batu.

\section{Produksi Kotoran}

Rata-rata produksi kotoran ternak sapi perah di Desa oro-oro Ombo adalah $32 \mathrm{~kg} / \mathrm{hari}$ berdasarkan hasil wawancara responden peternak, dimana $67 \%$ peternak menyatakan bahwa produksi kotoran sapi perah 32 $\mathrm{kg} / \mathrm{hari}$.

\section{Nilai kalor biogas}

Nilai kalor tipikal biogas adalah $20-26 \mathrm{MJ} / \mathrm{m}^{3}$ biogas [32]. Nilai kalor sebesar $26 \mathrm{MJ} / \mathrm{m}^{3}$ digunakan dalam penelitian ini

4. Kesetaraan nilai kalor per $\mathrm{m}^{3}$ biogas kotoran ternak sumber energi fosil dengan

Formulasi untuk menghitung Kebutuhan energi untuk memasak yang dilihat dari karakteristik konsumsi bahan bakar masyarakat untuk memasak menggunakan standar pada Tabel 1 [33]

Tabel 1: Kesetaraan nilai kalor per $\mathrm{m}^{3}$ biogas dengan sumber energi fosil.

\begin{tabular}{l|r|l}
\hline SUMBER ENERGI & KESETARAAN & \multicolumn{1}{|c}{ UNIT } \\
\hline LPG & 0,46 & kilogram $(\mathrm{kg})$ \\
Minyak Tanah & 0,00062 & meter kubik $\left(\mathrm{m}^{3}\right)$ \\
Minyak Solar & 0,00052 & meter kubik $\left(\mathrm{m}^{3}\right)$ \\
Bensin & 0,00080 & meter kubik $\left(\mathrm{m}^{3}\right)$ \\
Kayu Bakar & 3,50 & kilogram $(\mathrm{kg})$ \\
\hline
\end{tabular}


Dengan menggunakan asumsi tersebut diaatas, maka total potensi produksi energi biogas di Dusun Dresel dihitung dengan rumus 1 sebagai berikut:

$$
E s_{\text {tot }}=N * W * C g * e
$$

dimana $\mathrm{Es}_{\text {tot }}$ merupakan total potensi produksi energi dalam $\mathrm{MJ}, \mathrm{N}$ adalah jumlah sapi perah, W merupakan berat kotoran ternak dalam $\mathrm{kg}, \mathrm{C}_{\mathrm{g}}$ adalah konstanta yang menunjukkan nilai potensi biogas yaitu $0,04 \mathrm{~m}^{3} / \mathrm{kg}$ kotoran sapi dan e adalah nilai kalor biogas yaitu $26 \mathrm{MJ} / \mathrm{m}^{3}$ biogas.

Sumber energi yang digunakan di lokasi studi adalah liquid petroleum gas (LPG) dan kayu bakar. Total konsumsi Kedua jenis sumber energi ini dihitung menggunakan rumus 2 berikut ini:

$$
E d_{\text {tot }}=\sum_{i=1}^{n} \frac{E_{i}}{c_{i}}
$$

Dimana $\mathrm{Ed}_{\text {tot }}$ merupakan total kebutuhan energi dalam MJ, Ei adalah kebutuhan energi per jenis sumber energi dan c adalah konstanta yang menunjukkan Kesetaraan nilai kalor per $\mathrm{m}^{3}$ biogas dengan LPG atau kayu bakar berdasarkan Tabel 1 .

\section{HASIL DAN DISKUSI}

\subsection{Gambaran Umum wilayah Studi.}

Jumlah rumah peternak di Dusun Dresel adalah 177 dengan jumlah total sapi perah sebanyak 873 ekor. Dari jumlah tersebut, sebanyak 118 ekor sudah diolah kotorannya sebagai sumber energi biogas, sedangkan sisanya belum dan sekedar dimanfaatkan sebagian untuk pupuk kandang. Hal ini menunjukkan baru sekitar 11,9\% rumah tangga peternak yang mengolah limbah ternak menjadi sumber energi biogas. Sebagian besar peternak non-biogas menyatakan minatnya untuk mengolah limbah ternak namun terkendala minimnya pengetahuan dan tingginya biaya konstruksi. Hasil survei menunjukkan bahwa LPG merupakan sumber energi utama di Dusun Dresel walaupun masih terdapat RT yang menggunakan kayu bakar. Pengeluaran untuk konsumsi energi masyarakat Dusun Dresel berkisar antara Rp 17.000-Rp 60.000 per bulan. Kondisi umum di Dusun Dresel terkait dengan pemanfaatan kotoran ternak dapat dlihat pada Gambar 3 dan Gambar 4.

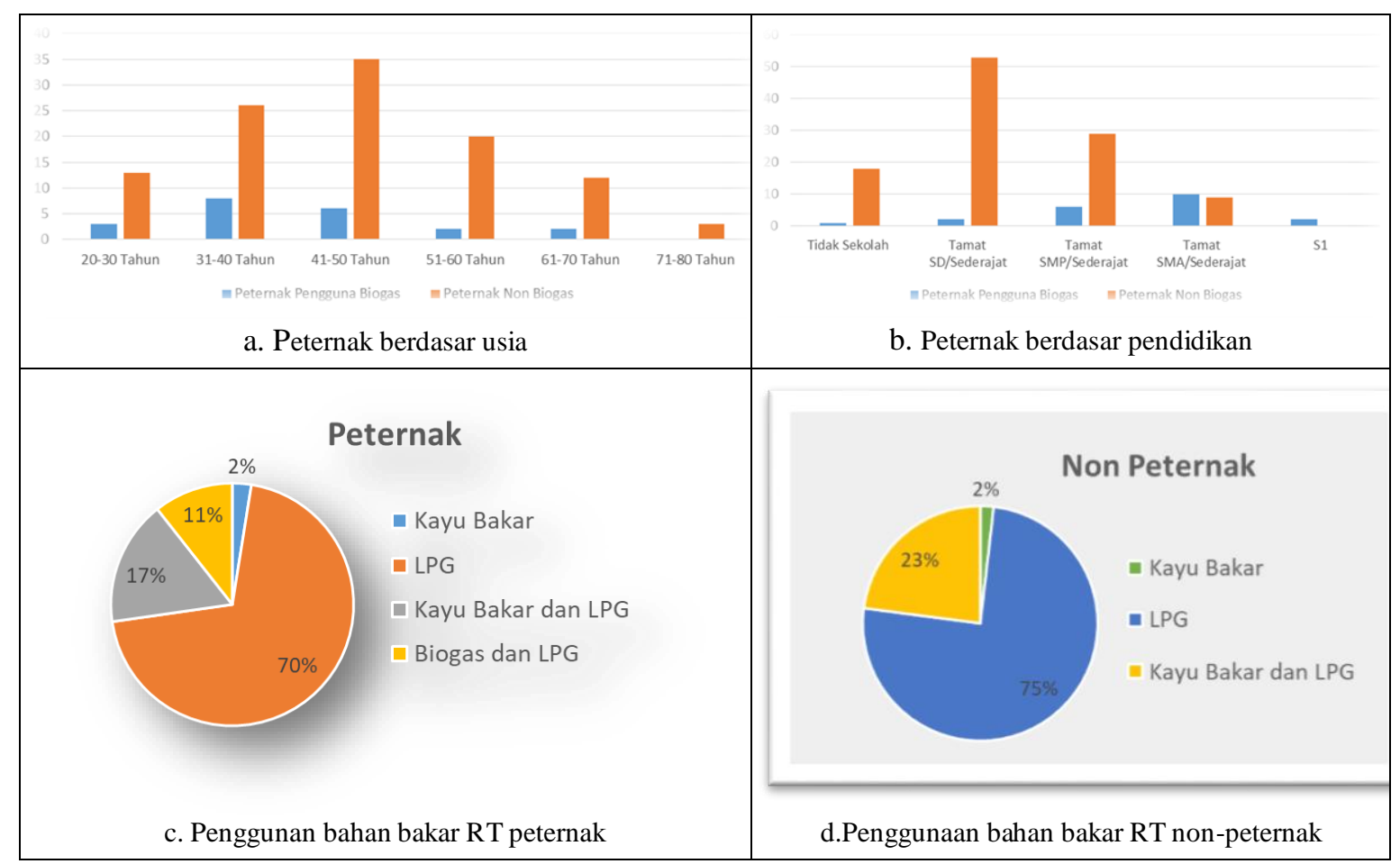

Gambar 3: karakteristik peternak di Dusun Dresel

\subsection{Pengelompokan Peternak Non-Biogas dan Non-peternak}

Pengelompokkan peternak di Dusun Dresel dilakukan berdasarkan hasil CSA dan Teknik overlay. Hasil dari CSA menunjukkan bahwa pola permukiman di Dusun Dresel adalah clustered atau mengelompok sehingga kondisi ini layak untuk pembangunan instalasi biogas komunal. Hasil ini menjadi dasar untuk langkap 
berikutnya yaitu teknik overlay dengan menggunakan 3 peta tematik yaitu kepemilikan ternak, ketersediaan lahan dan kontur tanah.

Data kepemilikan ternak menjukkan bahwa terdapat 20 RT yang memiliki maksimal 2 ekor sapi sedangkan jumlah minimal ternak yang harus dimiliki oleh peternak sebanyak 3 ekor. Namun dalam penelitian ini, output yang dihasilkan adalah instalasi biogas (biodigester) komunal sehingga 20 RT ini dapat digabungkan dengan anggota peternak yang lainnya.

Unit pengolahan biogas yang dikembangkan di Indonesia adalah dengan tipe kubah tetap yang berasal dari beton dengan kapasitas pengolahan $4 \mathrm{~m}^{3}-12 \mathrm{~m}^{3}$. Luas lahan minimal yang dibutuhkan untuk membangun biogas dengan kapasitas $4 \mathrm{~m}^{3}$ adalah $14 \mathrm{~m}^{2}$ sehingga ketersediaan lahan dinilai berdasarkan luas lahan minimal. Dari total 177 RT peternak non-biogas, sebanyak 80 (44\%) peternak tidak memiliki lahan yang cukup, sedangkan sebanyak 97 (56\%) peternak memiliki lahan yang cukup. Peternak dengan lahan cukup kemudian di nilai kelayakannya berdasarkan kontur tanah. Analisis baik menggunakan peta maupun pengamatan di lapangan menunjukkan bahwa tidak ada satu pun dari lahan-lahan tersebut yang memiliki kontur melebihi 5 derajat dan terletak lebih tinggi dari kandang sapi sehingga semua lahan tersebut dapat digunakan sebagai lokasi pembangunan biodigester. Hasil overlay menghasilkan 43 kelompok dengan parameter masing-masing seperti dapat dilihat pada Tabel 2

Table 2: Hasil Pengelompokkan Peternak Non-Biogas.

\begin{tabular}{|c|c|c|c|c|c|c|c|}
\hline PARAMETER & & & & & & & \\
\hline Kepemilikan Ternak & 3-4 & $5-6$ & $7-8$ & $9-10$ & $11-12$ & $>12$ & Keterangan \\
\hline $\begin{array}{l}\text { Jumlah ternak } \\
\text { kelompok }\end{array}$ & 0 & 0 & 7 & 2 & 8 & 25 & $\begin{array}{l}\text { Berdasarkan jumlah total ternak yang di- } \\
\text { miliki kelompok peternak 100\% } \\
\text { mencukupi untuk pembangunan reaktor bi- } \\
\text { ogas. }\end{array}$ \\
\hline $\begin{array}{l}\text { Ketersediaan Lahan } \\
\text { Minimal }\left(\mathbf{m}^{2}\right)\end{array}$ & 14-17 & $18-25$ & $26-35$ & $36-48$ & 49 & $>49$ & \multirow{2}{*}{$\begin{array}{l}\text { Berdasarkan jumlah sisa lahan yang dimil- } \\
\text { iki kelompok peternak } 100 \% \text { mencukupi } \\
\text { untuk pembangunan reaktor biogas. }\end{array}$} \\
\hline $\begin{array}{l}\text { Luasan lahan } \\
\text { kelompok }\end{array}$ & 19 & 15 & 9 & 0 & 0 & 0 & \\
\hline
\end{tabular}

\subsection{Penentuan Ukuran dan Lokasi Biodigester}

Tabel 3 menjadi acuan dalam menentukan ukuran dan lokasi pembangunan biodigester di Dusun Dresel. Setelah melalui observasi di lapangan guna validasi hasil perhitungan, maka didapatkan hasil seperti tercantum pada Tabel 3 .

Table 3: Hasil Pengelompokkan Peternak Non-Biogas.

\begin{tabular}{c|c|c}
\hline UKURAN BIODIGESTER $\left(\mathbf{m}^{\mathbf{3}}\right)$ & $\begin{array}{c}\text { JUMLAH } \\
\text { KELOMPOK }\end{array}$ & PROSENTASE \\
\hline 4 & 18 & $42 \%$ \\
6 & 15 & $35 \%$ \\
8 & 10 & $23 \%$ \\
10 & 0 & $0 \%$ \\
12 & 0 & $0 \%$ \\
Total & $\mathbf{4 3}$ & $\mathbf{1 0 0 \%}$ \\
\hline
\end{tabular}

\subsection{Ketersediaan dan Kebutuhan Biogas}

Perhitungan ketersediaan energi biogas dilakukan berdasarkan dimensi biodigester komunal kelompok peternak non-biogas, sedangkan kebutuhan energi biogas dihitung sesuai dengan konsumsi energi tiap anggota kelompok baik peternak mauppun non-peternak. Tabel 4 menunjukkan Penentuan RT non-peternak dan distribusi energi dimana hasil perhitungan produksi dan penggunaan biogas kelompok peternak menghasilkan sisa energi yang dapat didistribusikan kepada 75 RT non-peternak dari total 109 RT.

Tabel 4: Distribusi Sisa Energi dari Kelompok Peternak kepada Rumah Tangga Non Peternak

\begin{tabular}{l|l|l|l|l|l|l|l|l}
\hline \multicolumn{3}{c|}{ KELOMPOK PETERNAK } & \multicolumn{5}{c}{ NON PETERNAK } \\
\hline \multirow{2}{*}{ Klaster } & $\begin{array}{c}\text { Nama } \\
\text { Ketua } \\
\text { Kelompok }\end{array}$ & $\begin{array}{c}\text { Sisa } \\
\text { Energi } \\
\left(\mathrm{m}^{3} / \text { hari }\right)\end{array}$ & Keterangan & $\begin{array}{c}\text { No. } \\
\text { Persil }\end{array}$ & Nama & $\begin{array}{c}\text { Kebutuhan } \\
\text { Bahan Bakar } \\
(\mathrm{m} 3 / \mathrm{hari})\end{array}$ & $\begin{array}{c}\text { Sisa } \\
\text { Energi } \\
\left(\mathrm{m}^{3} / \text { hari }\right)\end{array}$ & $\begin{array}{c}\text { Kecu- } \\
\text { kupan }\end{array}$ \\
\hline 1 & Choirul & 35,41 & Berlebih & 266 & Pranoto & 0,50 & 15,86 & Cukup \\
\hline
\end{tabular}




\begin{tabular}{|c|c|c|c|c|c|c|c|c|}
\hline \multicolumn{4}{|c|}{ KELOMPOK PETERNAK } & \multicolumn{5}{|c|}{ NON PETERNAK } \\
\hline Klaster & $\begin{array}{c}\text { Nama } \\
\text { Ketua } \\
\text { Kelompok }\end{array}$ & $\begin{array}{c}\text { Sisa } \\
\text { Energi } \\
\left(\mathrm{m}^{3} / \text { hari }\right)\end{array}$ & Keterangan & $\begin{array}{l}\text { No. } \\
\text { Persil }\end{array}$ & Nama & $\begin{array}{c}\text { Kebutuhan } \\
\text { Bahan Bakar } \\
\text { (m3/hari) }\end{array}$ & $\begin{array}{c}\text { Sisa } \\
\text { Energi } \\
\left(\mathrm{m}^{3} / \text { hari }\right)\end{array}$ & $\begin{array}{l}\text { Kecu- } \\
\text { kupan }\end{array}$ \\
\hline 2 & Taru & 32,63 & Berlebih & 262 & Bardi & 0,43 & 14,51 & Cukup \\
\hline 3 & Sunarto & 33,23 & Berlebih & 254 & Liayah & 0,43 & 13,76 & Cukup \\
\hline 4 & Slamet & 17,24 & Berlebih & 250 & Yasemat & 0,43 & 6,61 & Cukup \\
\hline 5 & Misiadi & 23,21 & Berlebih & 243 & Tarmun & 0,22 & 9,39 & Cukup \\
\hline 7 & Wanaji & 22,73 & Berlebih & 294 & Budi & 1,08 & 10,87 & Cukup \\
\hline \multirow[t]{2}{*}{8} & Badri & 26,23 & Berlebih & 298 & Deden & 0,43 & 4,66 & Cukup \\
\hline & & & & 300 & Indah Harto & 0,43 & & \\
\hline 9 & Paidi & 14,49 & Berlebih & 307 & Iwan & 0,22 & 6,11 & Cukup \\
\hline 10 & Tamat & 37,73 & Berlebih & 80 & Okky & 0,86 & 15,70 & Cukup \\
\hline 11 & Pi'i & 9,15 & Berlebih & 88 & Edi & 0,43 & 3,28 & Cukup \\
\hline 12 & $\begin{array}{l}\text { Arif } \\
\text { Setiawan }\end{array}$ & 30,46 & Berlebih & 74 & Rusmiati & 0,65 & 12,13 & Cukup \\
\hline 13 & Murti & 8,02 & Berlebih & 287 & Apandi & 0,22 & 3,04 & Cukup \\
\hline \multirow[t]{2}{*}{14} & Dewi & 37,75 & Berlebih & 289 & Harmanu & 0,43 & 16,70 & Cukup \\
\hline & & & & 284 & Hidayatul & 0,22 & & \\
\hline 16 & R. Hidayat & 23,67 & Berlebih & 64 & Munawir & 0,22 & 10,53 & Cukup \\
\hline \multirow[t]{3}{*}{17} & Dulasim & 21,11 & Berlebih & 60 & Leksono & 0,43 & 8,25 & Cukup \\
\hline & & & & 56 & Nurcholis & 0,22 & & \\
\hline & & & & 55 & Wikuh & 0,65 & & \\
\hline \multirow[t]{5}{*}{18} & Herman & 22,58 & Berlebih & 36 & H. Wariadi & 0,86 & 6,14 & Cukup \\
\hline & & & & 29 & Franky & 0,72 & & \\
\hline & & & & 28 & Andri & 0,43 & & \\
\hline & & & & 33 & Juliawan & 0,43 & & \\
\hline & & & & 32 & Anang & 1,08 & & \\
\hline \multirow[t]{6}{*}{19} & Henni & 37,53 & Berlebih & 14 & Sigit & 0,43 & 15,18 & Cukup \\
\hline & & & & 17 & Wijayanto & 0,22 & & \\
\hline & & & & 19 & Atma & 0,22 & & \\
\hline & & & & 21 & Budi & 0,43 & & \\
\hline & & & & 22 & Kusnanto & 0,43 & & \\
\hline & & & & 23 & Ansor & 0,22 & & \\
\hline \multirow[t]{4}{*}{20} & Wandi & 13,65 & Berlebih & 49 & Fakih & 0,87 & 4,00 & Cukup \\
\hline & & & & 47 & Nuriyanto & 0,65 & & \\
\hline & & & & 46 & noryanto & 0,22 & & \\
\hline & & & & 43 & Tarmin & 0,43 & & \\
\hline \multirow[t]{3}{*}{21} & Said & 19,30 & Berlebih & 44 & Nur Rochim & 0,65 & 6,23 & Cukup \\
\hline & & & & & Yunarko & 0,43 & & \\
\hline & & & & & Subagio & 0,43 & & \\
\hline 23 & Yudi & 15,14 & Berlebih & 84 & Luluk W & 0,65 & 9,18 & Cukup \\
\hline \multirow[t]{2}{*}{24} & Kusen & 19,74 & Berlebih & 95 & Friyadi & 0,65 & 7,11 & Cukup \\
\hline & & & & & Sumitro & 0,43 & & \\
\hline \multirow[t]{4}{*}{25} & Kartini & 39,03 & Berlebih & 183 & Yayuk & 0,86 & 15,15 & Cukup \\
\hline & & & & 182 & Luluk & 0,65 & & \\
\hline & & & & 189 & Efendi & 0,43 & & \\
\hline & & & & 191 & Siti & 0,86 & & \\
\hline \multirow[t]{2}{*}{26} & Sulkan & 25,14 & Berlebih & 197 & Heru & 0,86 & 8,70 & Cukup \\
\hline & & & & 195 & Nurrochim & 0,65 & & \\
\hline
\end{tabular}




\begin{tabular}{|c|c|c|c|c|c|c|c|c|}
\hline \multicolumn{4}{|c|}{ KELOMPOK PETERNAK } & \multicolumn{5}{|c|}{ NON PETERNAK } \\
\hline Klaster & $\begin{array}{c}\text { Nama } \\
\text { Ketua } \\
\text { Kelompok }\end{array}$ & $\begin{array}{c}\text { Sisa } \\
\text { Energi } \\
\left(\mathrm{m}^{3} / \text { hari }\right)\end{array}$ & Keterangan & $\begin{array}{l}\text { No. } \\
\text { Persil }\end{array}$ & Nama & $\begin{array}{l}\text { Kebutuhan } \\
\text { Bahan Bakar } \\
\text { (m3/hari) }\end{array}$ & $\begin{array}{c}\text { Sisa } \\
\text { Energi } \\
\left(\mathrm{m}^{3} / \text { hari }\right)\end{array}$ & $\begin{array}{l}\text { Kecu- } \\
\text { kupan }\end{array}$ \\
\hline & & & & 193 & Widodo & 0,65 & & \\
\hline \multirow[t]{2}{*}{27} & Sunarsih & 28,79 & Berlebih & 202 & Dwi Ratno & 0,50 & 12,42 & Cukup \\
\hline & & & & 199 & Ruyat & 0,22 & & \\
\hline \multirow[t]{4}{*}{28} & Sukinem & 20,30 & Berlebih & 210 & Endri & 0,22 & 7,34 & Cukup \\
\hline & & & & 176 & Suliamat & 0,65 & & \\
\hline & & & & 173 & Hariono & 0,22 & & \\
\hline & & & & 171 & Jumari & 0,50 & & \\
\hline \multirow[t]{2}{*}{30} & Sutrino & 36,22 & Berlebih & 109 & Mustapa & 0,22 & 14,95 & Cukup \\
\hline & & & & 106 & Luluk & 0,65 & & \\
\hline \multirow[t]{2}{*}{31} & syahputra & 30,89 & Berlebih & 114 & Susilo & 0,86 & 12,13 & Cukup \\
\hline & & & & 110 & Sukari & 0,22 & & \\
\hline 33 & Purnomo & 15,56 & Berlebih & 125 & Burhan & 0,65 & 6,07 & Cukup \\
\hline \multirow[t]{2}{*}{34} & Edwin & 19,18 & Berlebih & 124 & Iwan & 0,43 & 7,65 & Cukup \\
\hline & & & & 119 & Munawaroh & 0,22 & & \\
\hline 37 & Wisnu & 12,55 & Berlebih & 100 & Suratih & 0,43 & 3,96 & Cukup \\
\hline \multirow[t]{2}{*}{38} & Murti & 23,43 & Berlebih & 205 & Budiono & 0,22 & 9,10 & Cukup \\
\hline & & & & 203 & Suparman & 0,50 & & \\
\hline \multirow[t]{4}{*}{39} & Miskan & 9,16 & Berlebih & 159 & Sahrodi & 0,43 & 1,35 & Cukup \\
\hline & & & & 160 & Firman & 0,43 & & \\
\hline & & & & 161 & Mugi & 1,08 & & \\
\hline & & & & 163 & Riwan & 0,43 & & \\
\hline \multirow[t]{2}{*}{40} & Supriyono & 7,87 & Berlebih & 73 & Maryono & 0,50 & 2,01 & Cukup \\
\hline & & & & 71 & Suparman & 0,6 & & \\
\hline \multirow[t]{2}{*}{41} & Jiarno & 8,72 & Berlebih & 6 & Wahyu & 0,43 & 2,63 & Cukup \\
\hline & & & & 4 & Najib & 0,22 & & \\
\hline \multirow[t]{2}{*}{42} & Supadi & 12,35 & Berlebih & 275 & Nariyo & 0,22 & 4,05 & Cukup \\
\hline & & & & 273 & Sutrino & 0,6 & & \\
\hline \multirow[t]{2}{*}{43} & Darto & 10,22 & Berlebih & 52 & Sujoko & 0,43 & 2,73 & Cukup \\
\hline & & & & 51 & Yendra & 0,94 & & \\
\hline \multicolumn{2}{|l|}{ Total } & 883,75 & & & & 40,73 & 843,02 & \\
\hline
\end{tabular}

Hasil perhitungan menunjukkan bahwa total, biogas yang dihasilkan oleh masing-masing kelompok beragam, yaitu berkisar antara 8,966 dan 39,68 m3/hari tergantng dari kapasitas biodigester yang digunakan berdasarkan data pada Tabel 3. Konsumsi energi masing-masing rumah tangga (RT) peternak berkisar mulai 0,65 hingga $3,48 \mathrm{~m} 3 /$ hari. Total potensi biogas yang dihasilkan dari pemanfaatan kotoran ternak oleh 43 kelompok adalah sebesar 944,64 $\mathrm{m}^{3} / \mathrm{hari}$ dengan nilai energi setara dengan 24.560,64 MJ. Total potensi kebutuhan energi RT dalam 43 kelompok peternak sebesar 82,59 $\mathrm{m}^{3} /$ hari. Nilai ini jika dikonversi ke dalam satuan energi, maka setara dengan 2.147,34 MJ/hari sehingga masih terdapat sisa energi sebesar 889,13 m²/hari (23.117,38 MJ/hari) yang dapat didistribusikan kepada RT non-peternak. Tingginya sisa energi disebabkan kebutuhan energi yang ada sebatas untuk memasak saja dan berdasarkan survei, rata-rata kebutuhan energi di Dusun Dresel sekitar LPG rata-rata 2 tabung seberat $3 \mathrm{~kg}$ dan kayu bakar sebanyak 5 ikat dengan berat $15 \mathrm{~kg} / \mathrm{ikat}$. Penentuan RT penerima distribusi biogas didasarkan pada jarak kedekatan dari hasil SCA sehingga 75 RT dari total 109 RT non-peternak dapat bergabung ke dalam 43 kelompok peternak yang kemudian disebut sebagai kelompok pengguna biogas. Tidak semua RT non-peternak dapat bergabung karena letak rumah melebihi $12 \mathrm{~m}$ yang merupakan jarak rata-rata antar rumah di Dusun Dresel serta lokasinya di seberang jalan sehingga jaringan distribusi tidak bisa mencapai lokasi tersebut tanpa membongkar jalan. Total kebutuhan energi RT kelompok pengguna biogas yang terdiri dari peternak dan non-peternak sejumlah 199 RT adalah sebesar 123,32 m3 biogas/hari atau setara 3206,32.MJ/hari yang dihitung berdasarkan jenis bahan bakar yang digunakan yaitu LPG dan kayu bakar. 


\section{KESIMPULAN}

Penelitian tentang pemanfaatan limbah ternak sebagai energi biogas di Dusun Dresel menghasilkan keluaran sebagai berikut:

1. Pengelompokkan peternak di Dusun Dresel berdasarkan minimal ketersediaan lahan $\left(14 \mathrm{~m}^{2}\right)$, kepemilikan peternak (minimal 2 sapi) dan kontur (maksimal 5 derajat) menghasilkan 43 kelompok.

2. Semua kelompok memiliki lahan cukup untuk membangun biodigester. Biodigester kapasitas $4 \mathrm{~m}^{3}$ dapat dibangun oleh 18 kelompok, biodigester kapasitas $6 \mathrm{~m}^{3}$ mampu dibangun oleh 15 kelompok dan 10 kelompok dapat membangun biodigester dengan kapasitas $8 \mathrm{~m} 3$.

3. Total potensi produksi biogas yng dapat dihasilkan adalah sebesar $8,96-39,68 \mathrm{~m}^{3} / \mathrm{hari}$ dan kebutuhan energi sebesar 0,65-3,48 $\mathrm{m}^{3} /$ hari. Perbandingan antara sediaan dan kebutuhan biogas di Dusun Dresel menunjukan bahwa jika peternak dalam semua kelompok beralih ke biogas, maka tingkat pemakaian hanya sebesar $8.7 \%$ sehingga masih terdapat sisa energi yang dapat didistribusikan ke keluarga nonpeternak.

4. Sisa energi biogas kelompok peternak mampu menyuplai $69 \%$ atau sebanyak $75 \mathrm{KK}$ non peternak

5. Total potensi energi yang dihasilkan adalah $24.560,64 \mathrm{MJ} /$ hari dan mampu menYuplai kebutuhan biogas peternak sebesar 2.147,34 MJ/hari sehingga masih terdapat 23.117,38 MJ/hari untuk didistribusikan kepada RT non-peternak

6. Dari total 109 RT, 75 RT non-peternak dapat bergabung ke dalam 43 kelompok peternak sehingga total kebutuhan biogas di Dusun Dresel adalah 3206,32.MJ/hari.

\section{DAFTAR PUSTAKA}

[1] YUANA, X., ZUO, J., "Pricing and affordability of renewable energy in China -A case study of Shandong Province", Renewable Energy, v. 36, n. 3, pp. 1111-1117, March 2011

[2] HAMID, R.G., BLANCHARD, R.E., "An assessment of biogas as a domestic energy source in rural Kenya: Developing a sustainable business model”, Renewable Energy, v. 121, pp. 368-376, June 2018

[3] WANG, C., ZHANG Y., ZHANG, L., PANG, M., "Alternative policies to subsidize rural household biogas digesters”, Energy Policy v. 93, pp. 187-195, June 2016

[4] ZHANG, L.X., WANG, C.B., SONG, B., "Carbon emission reduction potential of a typical household biogas system in rural China", Journal of Cleaner Production, v. 47, pp. 415-421, May 2013.

[5] RAO, V.P., BARAL, S.S., DEY, R., MUTNURI, S., "Biogas generation potential by anaerobic digestion for sustainable energy development in India", Renewable and Sustainable Energy Reviews, v. 14, n. 7, pp. 2086-2094, September 2010.

[6] KHAN, U.K., MAINALI, B., MARTIN, A., SILVIERA, S., "Techno-economic analysis of small scale biogas based polygeneration systems: Bangladesh case study. Sustainable Energy Technologies and Assessments, v. 7, pp. 68 - 78, September 2014

[7] ANTHONY, D.O., "Renewable energy: externality costs as market barriers", Energy Policyv, v. 34, n. 5, pp. 632-642, March 2006

[8] ANNA, P., "Renewable energy in South Africa: potentials, barriers and options for support", Energy Policy v. 38, n. 9, pp. 4945-4954, September 2010.

[9] IGONI, A.H., AYOTAMUNO, M.J., EZE, C.L., OGAJI, S.O.T., PROBET, S.D., "Designs of anaerobic digesters for producing biogas from municipal solid-waste", Applied Energy, v. 85, n. 6, pp. 430-438, June 2008.

[10] ZUBARYEVA, A., ZACCARELLI, N., DEL GIUDICE, C., ZURLINI, G., "Spatially explicit assessment of local biomassas availability for distributed biogas production via anaerobic co-digestion - Mediterranean case study" Renewable Energy, v. 39, pp. 261-270, March 2012.

[11] SUGIYONO, A., FITRIANA, I., ANINDHITA, FNU., WAHID, LOMA., ADIARSO. 2018. Outlook Energi Indonesia 2017. Inisiatif pengembangan teknologi energi bersih, Jakarta. Pusat Teknologi Sumber Daya Energi dan Industri Kimia, Badan Pengkajian dan Penerapan Teknologi (BPPT), 2017

[12] WIBOWO, R., "Analisis Thermal Nilai Kalor Briket Ampas Batang Tebu dan Serbuk Gergaji”, Jurnal Rekayasa Mesin, v. 10, n. 1, pp. $9-15,2019$

[13] NUGRAHA, A., WIDODO, A., WAHYUDI, S., "Pengaruh Tekanan Pembriketan dan Persentase Briket Capuran Gambut dan Arang Pelepah Daun Kelapa Sawit terhadap Karaketeristik Pembakaran Briket", 
Jurnal Rekayasa Mesin, v. 8, n. 1, pp. 29-36, 2017

[14] MORERO, B., GROPPELLI, E., CAMPANELLA, E.A., "Life cycle assessment of biomethane use in Argentina", Bioresource Technology, v. 182, pp. 208 - 216, April 2015.

[15] HUTTUNEN, S., MANNINEN, K., LES KINEN, P., "Combining biogas LCA reviews withstakeholder interviews to analyse life cycle impacts at a practical level", Journal of Cleaner Production, v. 80, pp. 5 - 16, October 2014.

[16] SILVA, S., ALCADA-ALMEIDA, L., DIAS, L.C., "Biogas Plants Site Selection. Integrating Multi Criteria Decision Aid methods and GIS techniques: A case study in a Portuguese region", Biomassas and Bioenergy, v. 71, pp. 58 - 68, December 2014.

[17] LYBAEK, R., KJAER T., "Pre-assessment of the circular economic benefits and challenges of biogas production in Denmark when utilizing sand bedding in dairy cow stables", Journal of Cleaner Production v. 219, pp. 268-277, May 2019.

[18] LOPEZ-VAZQUEZ, C.M., MITHAIWALA, M., MOUSSA, M.S., BRDJANOVIC, D., "Coupling ASM3 and ADM1 for wastewater treatment process optimisation and biogas production in a developing country: Case-study Surat, India", Journal of Water, Sanitation and Hygiene for Development, v. 3, n. 1, pp. 12-25, March 2013.

[19] MEIDIANA, C., SELVIA, S.I., DINANTI, D. (2018) “Increasing Farmers' Affordability for Anaerobic Digester Construction in Rural Area Using Spatial Cluster Analysis”, In: McLellan, B. (eds), Sustainable Future for Human Security, Part III, Singapore, Springer Nature Singapore Pte Ltd., 2018

[20] KURKA., T., JEFFERIES, C., BLACKWOOD, D., "GIS-based location suitability of decentralized, ‘medium scale bioenergy developments to estimate transport $\mathrm{CO} 2$ emissions and cost", Biomassas Bioenergy, v. 46, pp. 366-379, November 2012.

[21] SUTANA, A., KUMAR, A., "Optimal siting and size of bioenergy facilities using geographic information system", Applied Energy, v. 94, pp. 193-201, June 2012.

[22] CHUKWUMA, E.C., "Facility location allocation modelling for bio-energy system in Anambra State of Nigeria: Integration of GIS and location model", Renewable Energy, v. 141, pp. 193-201pp.460-467, October 2019.

[23] DAGNALL S, HILL J, PEGG, D., "Resource mapping and analysis of farm livestock manures-assessing the opportunities for biomass-to-energy schemes", Bioresource Technology, v. 71, pp. 225-234, February 2000

[24] SCARLAT, N., FAHL, F., DALLEMAN, J., MONFORTI, MOTOLA, V., “A spatial analysis of biogas potential from manure in Europe", Renewable and Sustainable Energy Reviews, v. 94, pp. 915-930, October 2018.

[25] ALI, M.M., NDONGO, M., BILAL, B., YETILMEZSOYC, K., YOUM, I., BAHRAMIANC, M., "Mapping of biogas production potential from livestock manures and slaughterhouse waste: A case study for African countries", Journal of Cleaner Production, v. 256, pp. 1-17, May 2020.

[26] GURUNG, A., KARKI, R., CHO, J.S., PARK, K.W., OH, SE., "Roles of renewable energy technologies in improving the rural energy situation in Nepal: Gaps and opportunities". Energy Policy, v. 62, pp. 1104-1109, November 2013.

[27] MULDER P, TEMBE J (2008) "Rural electrification in an imperfect world: a case study from Mozambique", Energy Policy, v. 36, pp. 2785-2794, August 2008

[28] VAISSI, S., SHARIFI, M., "Integrating multi-criteria decision analysis with a GIS-based siting procedure to select a protected area for the Kaiser's mountain newt, Neurergus kaiseri (Caudata: Salamandridae)", Global Ecology and Conservation, v. 20, pp. 1-15, October 2019

[29] STESSENS, P., CANTERS, F., HUYSMANS, M., KHAN, A.Z., "Urban green space qualities: An integrated approach towards GIS-based assessment reflecting user perception”, Land Use Policy, v. 91, pp. $1-15$, February 2020

[30] MONTEIRO, E, MANTHA, V, ROUBOA, A., "Prospective application of farm cattle manure for bioenergy production in Portugal", Renewable Energy", v. 36, n. 2, pp. 627-631, February 2011.

[31] WAHYUNI, S., Biogas Energi Alternatif Pengganti BBM, Gas, dan Listrik, Jakarta, PT. Agro Media Pustaka., 2013.

[32] LPELC (Livestock and Poultry Environmental Learning Community), https://lpelc.org/biogas-utilization-and-cleanup). Diakses: Agustus.2019 
[33] DEPARTEMEN PERTANIAN, Program Bio Energi Pedesaan-Biogas Skala Rumah Tangga. Jakarta, Ditjen PPHP - Departemen Pertanian, 2006. 